\title{
The Impact of Japanese Economic Cooperation on Asian Economic Development
}

\author{
Kenichi KAWASAKI \\ Senior Research Fellow, ESRI and Consulting Fellow, RIETI
}

\begin{abstract}
The main objective of this paper is to overview the developments of Japan's ODA and assess, in a quantitative manner, their economic impacts on Asian countries. The benefits of two alternative measures - one from capital formation by Japan's ODA loans and the other from import liberalization in the Japanese market-are compared. Those economy-wide impacts of aid and trade on six Asian countries - China, Indonesia, Malaysia, the Philippines, Thailand, and Vietnam-are estimated by a CGE model of global trade, incorporating a certain mechanism of dynamic capital formation. Japan's ODA loans are effective for economic growth in the Asian countries. Real GDP gains range from 0.1 to 1.6 per cent annually. Trade liberalization is efficient to improve economic welfare. Utility gains range from 0.2 to 1.9 per cent, which exceed those on account of Japan's ODA. Variations in those economic impacts are much more significantly observed when examined by sector.
\end{abstract}

\section{Introduction}

Expansion of international trade and investment has enhanced the mutual interdependencies of the world's economies, both within the developed economies and between developed and developing economies. The role the developed economies will play in the sustainable development of the developing economies has never been as important as it is now. The quality of aid from the developed economies has been reviewed on a number of occasions. Earlier arguments in the World Bank's publication, Assessing Aid (1998) have also been re-examined.

Throughout the 1990s, Japan experienced persistent stagnant economic activities. In contrast, most of Japan's Asian neighboring economies have succeeded in recovering from the Asian crisis of 1997 and are starting to grow again. Recently, however, Japan's massive amount of ODA to the Asian economies has been questioned by the Japanese people. ODA has to be provided with a view towards its effectiveness and efficiency in a selective manner.

This paper will provide a quantitative analysis, using economic model simulations, of the impact of Japanese economic cooperation on Asian economic development. Model simulations can provide helpful insights into some of the key mechanisms for possible economic developments, and also indicate orders of magnitude. Where differences of views persist, the modeling can provide a framework within which to identify areas of disagreement more clearly. The main purpose of this paper is to present such economic model simulations.

This paper is organized as follows. After this introduction, developments of Japan's ODA will be discussed in Chapter II. Asian economic developments, and in particular trade and investment with Japan, will be briefly examined in Chapter III. Following the presentation 
of the framework of CGE model simulations in Chapter IV, those results will be discussed in Chapter V. The paper will conclude with Chapter VI.

\section{Developments in Japan's ODA}

Economic cooperation measures of the developed countries essentially have their own features. Japan's ODA has several salient features that differ from that of other countries. Those features may be a reflection of a unique Japanese history, having experienced the phenomenon of originally being a large aid recipient ${ }^{1}$ to becoming the world's top donor. Japan has demonstrated a successful model of economic developments as an aid recipient.

\section{1. Aid Philosophy}

Japan has often been criticized for having no clear or consistent ideas that underlie its Japanese economic cooperation policies. One argument-though it is not necessarily clear- is that Japan is attempting to support the self-help efforts of developing countries. ${ }^{2}$ But what constitutes an aid philosophy based on the concept of self-help? According to Nishigaki and Shimomura (1999), two essential elements are emphasized.

The first is the underlying conviction that economic development is only possible when the government and citizens of a developing country make unremitting efforts to improve their current conditions. Unless the people of a developing country take it upon themselves to make the necessary efforts and sacrifices, neither aid nor development will ultimately be successful. The efforts of the developing country are central; foreign aid merely has the supporting role of making it somewhat easier for those efforts to bear fruit.

The second essential element has to do with where the focus of aid implementation should lie. Japan's basic approach is that an aid donor should not impose its plans on aid recipients; rather, it should do its best to search out and discover nascent independent projects in a developing country and then lend a deft and experienced helping hand to ensure that small seeds can grow to fruition.

In 1992, the Japanese cabinet approved the ODA Charter, which could be the first comprehensive statement of Japan's aid philosophy and basic policies. The Charter states that Japan's ODA will be provided in accordance with the principles of the United Nations (UN) Charter, especially those of sovereign equality and non-intervention in domestic matters, as well as the following four principles:

i. $\quad$ Environmental conservation and development should be pursued in tandem;

ii. Any use of ODA for military purposes or for aggravation of international conflicts should be avoided;

iii. Full attention should be paid to trends in recipient countries' military expenditures, their development and production of mass destruction weapons and missiles, their export and import of arms, etc., so as to maintain strengthen international peace and stability, and from the viewpoint that developing countries should place appropriate

${ }^{1}$ After World War II, Japan's economic reconstruction was largely undertaken through aid from abroad. The volume of Japanese borrowing from the World Bank was the second largest in the world in the early 1960s.

${ }^{2}$ This idea may be one justification of Japan's aid policy, which is formally based on requests from recipient countries. 
priorities in the allocation of their resources on their own economic and social development;

iv. Full attention should be paid to efforts for promoting democratization and introduction of a market oriented economy, and the situation regarding the securing of basic human rights and freedoms in the recipient country.

Moreover, in line with the basic philosophy and the principles of the ODA Charter, the "Medium-Term Policy on Official Development Assistance" was compiled and published in August 1999. This aimed to provide a clear and concrete path for Japan's ODA over a five-year period.

\section{2. Recent Trends ${ }^{3}$}

In 1991, the volume of Japan's ODA in terms of net-disbursement ${ }^{4}$ exceeded that of the United States and became the largest in the world. Japan had maintained this position of top donor country in the world in the 1990s, ${ }^{5}$ during which time Japan's ODA accounted for around a fourth or fifth of the total world aid.

Japan's aid performance, however, is not so excellent when looked at in terms of relative position such that by the ratio over GNI rather than in terms of absolute volume. According to OECD (2002), Japan's ODA over GNI ratio was 0.23 per cent in 2001, which is around the DAC (Development Assistance Committee) member countries average of 0.22 per cent. Although this is also at the level of the majority of DAC member countries, it is very far from the international target of 0.7 per cent that the five distinguished countries of Denmark, Norway, Luxembourg, the Netherlands and Sweden have already satisfied. ${ }^{6}$

ODA is comprised of several schemes and can be classified in several ways. One is the determination of ODA as a grant or a loan, depending on whether the initial disbursement is to be repaid. The ratio of loans, in terms of net-disbursement, was around 30 per cent over the total of Japan's ODA in fiscal 2001. Using an international comparison, one distinguishing feature of Japan's ODA is this high ratio of loans. This may be a reflection of Japan's aid philosophy, as discussed above, which is to support the self-help efforts of developing countries.

The primary objective of economic cooperation measures including ODA loans must be to contribute to the steady and sustainable economic growth of the developing economies and the enhancement of their living standards. Therefore, ODA loans are provided on more favorable terms than, say, commercial finance, i.e. with lower interest rates and longer repayment periods. According to MoFA (2003), the average interest rate of ODA loans in fiscal 2001 was 1.45 per cent and the average repayment period was 35 years, including a grace period of 10 years.

Since ODA loans are to be repaid, distributions by region and sector are different from

\footnotetext{
${ }^{3}$ The survey of recent trends in Japan's ODA in this section refers to Nishigaki and Shimomura (1999).

${ }^{4}$ This is the net amount of deducting the repayments of loans from the total amount of aid.

${ }^{5}$ According to OECD (2002), the volume of Japan's ODA was the second largest in the world in 2001 following that of the United States.

${ }^{6}$ It may be noted that the relative size of the Japanese government is not so large as the other developed countries in terms of the share of government revenues and expenditures in national economy measured by GDP. Therefore, Japan's ODA share of government expenditures may not be son low relative to other countries, as shown in the ODA over GNI ratio.
} 
those of other aid measures such as grant aid, which is not to be repaid. By region, it is shown in Chart 1 that the ratio of loans to Asia is very high compared with other regions. In contrast, the ratio of grant aid to Africa is strikingly high and that to Asia is relatively low. ODA loans are mainly provided to relatively higher-income developing countries, whose income levels exceed a certain level and have sufficient resources to repay the loans. Grants are primarily intended to aid lesser developing countries with lower living standards.

\section{[Chart 1: Geographical Distribution of Japan’s ODA (2001)]}

Moreover, destinations of Japan's ODA loans concentrate to several Asian countries. According to MoFA (2003), the largest four recipients-Indonesia, India, China and Vietnam-shared more than 70 per cent in total in 2001. While, in terms of the cumulated amount of ODA loans at the end of fiscal 2001, Indonesia is the top recipient receiving 3.6 trillion yen on the Exchange of Note basis. This is followed by China ( 2.8 trillion yen), India (2.0 trillion yen), the Philippines (2.0 trillion yen) and Thailand (1.9 trillion yen).

By sector, the ratio of ODA loans is high for economic infrastructure. This includes energy and transportation infrastructures, i.e., the building of roads, railways, bridges, and ports. The ratio of ODA loans for social infrastructure, however, is low. It might have been expected that an investment in those economic infrastructures would generate direct and indirect economic benefits. Therefore, such revenues would offset the large-scale initial costs and enable the recipient countries to repay the principal and interest of the project. Moreover, grant aid has been allocated mainly to those sectors with low economic profitability. Those are education, health, and sanitation in the social infrastructure sector and agriculture in the production sector.

Another feature of Japan's ODA could be suggested regarding its qualitative rather than quantitative features. Among others, grant share is one indicator that measures the advantages of ODA from a financial perspective. On the other hand, the tying status of contract and procurement of the project is also an important condition for developing countries. However, these two criteria-concessionality and openness-suggested a kind of trade off. Although Japan's grant share is the lowest among major donor countries, its untied share is ranked among the highest. Any discussion of the quality of ODA must look at multiple criteria.

\section{3. Future Reform}

Since the beginning of the 1990s, when Japan's bubble first began to burst, Japanese economic activities have generally been stagnant, with occasional signs of modest improvement. Japan has continued to face serious economic and fiscal constraints. The continued need for massive amounts of ODA has clearly been questioned by the Japanese people, who recognize the severe economic conditions at home. In fact, the ODA budget for fiscal 2001 was cut by 3 per cent followed by much more significant cut of 10 per cent in fiscal 2002. The Japanese government is required to improve the efficiency, effectiveness, and transparency of ODA in order to earn the understanding and support of its people.

In addition to the total amount of ODA, its allocation both by region and sector would be reviewed in a selective manner. It must be noted that this does not necessarily mean that ODA in general or ODA loans in particular would significantly be cut in all the regions in a common fashion. In fact, for example, as shown in Chart 2, the current level of ODA distributes widely around a theoretical convex curve ${ }^{7}$; it is expected that the relative size of aid

\footnotetext{
${ }^{7}$ The curve is drawn for selected countries of so called "annual consultation countries” for ODA
} 
will increase to a certain level according to economic development, which is measured by per capita GDP, but will decrease as the economy "graduates” from receiving aid.

\section{[Chart 2: Relative Level of ODA]}

Several reasons for the variation in per capita ODA levels among countries in light of their stage of economic development can immediately be pointed out. The excess of ODA in Sri Lanka and shortage of ODA in China and India in this regard may be a reflection of the fact that population is not a significant indicator for the size of ODA. The appropriate amount of ODA to each country may vary when seen in terms of total values or scaled by a certain macro indicator such as population. On the other hand, the lower levels of ODA in Morocco and Tunisia may be attributed to the geographical bias of Japan's ODA going largely to Asian neighboring economies.

Earlier studies that focused on identifying the factors deciding the distribution of Japan's ODA among the countries ${ }^{8}$ found a certain correlation between the amount of ODA and economic factors such as population, income level, and trade, but at the same time attributed more or less importance to social and political factors and geographical bias. There may be a good reason why such an argument is made, since Japan's ODA has been said to be a "tool" or even a "weapon" in foreign affairs and diplomatic policy. It is not necessarily decided by economic factors alone. However, it has been difficult for economists to measure such intangible diplomatic factors. Policy makers may be in an advantageous position to quantify or, if difficult, even to qualify those factors with enough accountability. Econometric studies in this field are beyond the scope of this paper, however.

Future assistance strategies, in particular those on ODA loans, could be reviewed by two steps. The first concerns the extent to which individual countries are significant to Japan as a recipient. This may mainly be determined by political and diplomatic factors. The second concerns what is considered to be the appropriate amount of ODA loans in each country. This will duly be considered from various economic aspects.

As far as significance as a recipient country is concerned, five main points would be assessed. First are political and economic relations to Japan. Second is conformity with the four principles of the ODA Charter, as discussed above. Third is economic performance in general, and fourth is appropriate development strategy and plan. Fifth is the ability to implement projects.

The appropriateness of ODA loan amounts would be reviewed in light of the following points. First, the impact of ODA loans on development strategy and plan will be checked. Second, past records may be referred to as well. Third, debt service ratio will be checked to confirm the debt sustainability of the recipient. Fourth and fifth, the relative size of Japan's aid will be compared both horizontally and vertically, one with the other recipients and two with the other donors.

\section{Japanese Trade and Investment in Asia}

loans. The figures for per capita ODA and GDP are averages of the four years 1997 - 2000. The convex shape is not always derived; it depends on the choice of country and period.

${ }^{8}$ See, for example, Shimomura et al. (1999). 
The Asian economies, including the Asian NIEs (Newly Industrialized Economies), ASEAN (Association of Southeast Asian Nations), and China have been the most dynamic part of the world economy during the last decade. Although several economies were significantly stricken by the Asian crisis of 1997, it is expected that these could be a reflection of short-term adjustments in international economic fundamentals; a temporary phenomena, in other words.

It has been stressed on a number of occasions and in various articles ${ }^{9}$ that the higher economic growths in this region have largely been led by expansion in exports as well as increases in foreign direct investment (FDI) inflows, whose rates were also higher than those of the world as a whole on average. The growth in exports and FDI inflows created "virtuous" cycles.

One typical feature in the development of Asian economies is that the higher economic growth in the region has been associated with the deepening of economic interdependence within the region. This feature may also be applied to Japan. Long-term trends in the share of selected Asian countries in the sources of Japanese imports are shown in Chart 3. Asian countries in total are becoming much more significant partners of Japanese trade.

\section{[Chart 3: Sources of Japan’s Imports]}

To be more specific, several key structural changes are pointed out. First, those Asian countries are much more important as source regions rather than destination regions. Second, what is striking is the rapid growth in both exports to and imports from China. The share of Japanese trade with China exceeded a tenth at the end of 1990s. Third, on the other hand, one distinguishing feature in view of relative position among countries is a larger drop in the share of Japanese imports from Indonesia. This would be a reflection of the structural changes in Japanese imports, in which the share of oils and raw commodities has declined substantially after the oil crises in the 1970s. It must be noted that Indonesia is no longer a special partner of Japanese trade as far as this figure of total share is concerned.

The developments of Japanese capital outflows to selected Asian countries are shown in Chart 4. Among others, trends in outward FDI and ODA loans ${ }^{10}$ are compared. ${ }^{11}$ It is shown that Japanese FDI flows into these Asian countries peaked out at around the time of the 1997 Asian crisis. $^{12}$ On the other hand, the amount of ODA loans corresponds to that of FDI in China, the Philippines, and Thailand at the end of the 1990s. Moreover, ODA loans have surpassed FDI in Indonesia and Vietnam. Although, the absolute volume of ODA loans in these five countries are in a relatively narrow range between 50 to 100 billion yen. It may be pointed out that ODA loans have played an important role of offsetting the declining trends in private

\footnotetext{
${ }^{9}$ See, for example, APEC (1995).

10 The figures in the chart are on a gross-disbursement basis, which are the total amount of new capital inflows to Asian countries not deducted from the amount of repayment of past loans.

${ }^{11}$ These two are different in the sense that FDI is private capital, while ODA is public capital. However, they share one common trait: they are spent largely on long-term physical investment, which forms capital stock, and which therefore expands production capacities, rather than on speculative investment that can be withdrawn quickly.

${ }^{12}$ It must be noted that FDI flows to China from the other countries remains large, amounting to around 40 to 50 billion US dollars in total including those from Japan in 2001, according to UNCTAD (2002). Japan's share in FDI flows to China is relatively low compared with that in other countries.
} 
capital inflows into these Asian countries. ${ }^{13}$

[Chart 4: Trends in Flows of FDI and ODA Loans]

\section{Framework of CGE Model Simulations}

To analyze the impact of Japanese economic cooperation measures, the Global Trade Analysis Project (GTAP) ${ }^{14}$ model is employed for model simulations. In this chapter, after a brief discussion on the past quantitative studies assessing aid and trade, an outline of the fundamental structure of the model is presented and simulation designs, including the assumptions of the experiments, are discussed.

\section{1. Past Assessments of Aid and Trade}

Assessing Aid, published by the World Bank in 1998, is "intended to bring the results of World Bank research on development policy issues to take stock of what is known and is not known." The two key messages concerning the effectiveness of aid in promoting growth and reducing poverty are "aid works in a good policy environment" and "assistance must be targeted more effectively to low-income countries with sound economic management." As far as quantitative assessment is concerned, it states, according to cross-country studies, that under the good-management environments, " 1 per cent of GDP in assistance translates to a sustainable increase in growth of 0.5 percentage points of GDP,” while it "reduces poverty by 1 per cent.”

However, these conclusions have been re-examined. Hansen and Tarp (2000), who address the aid-growth literature, reached rather different conclusions from those presented in Assessing Aid. It is pointed out that a coherent and positive picture of the aid-growth linkage emerges, even in countries hampered by an unfavorable policy environment. It is demonstrated that much is still not known about the complex linkage between aid, policy, and growth.

In the areas of global trade policies, the focus has been on relations between developed countries and developing countries. Among others, Shoven and Whalley (1992), who analyze the impact of protectionism of developed countries on developing countries by the General Equilibrium model of global trade, argue that the trade costs that developed countries impose on developing countries would be approximately equivalent to the values of annual aid flows. Therefore, it is pointed out that the effects of aid and trade on developing countries would offset one another.

Recently, poverty reduction is an increasingly important issue not just in terms of aid policies but also in conjunction with global trade liberalization. Most past studies that have analyzed the impact of trade liberalization on poverty have looked at average macroeconomic effects. However, it is misleading to judge from average effects, in light of the fact that poverty is not always reduced even under economic growth; therefore, improvements in living standards as measured by per capita income on average are not always a given. Hertel et al. (2002) show one departure that focuses on the impact of trade liberalization on households at the edge of poverty. It is expected that ambitious research will continue to push forward, addressing limitations mainly in data availability.

13 Japan's Other Official Finance (OOF) has also played an important role in response to capital shortage according to Asian financial crisis.

${ }^{14}$ See Hertel (1997) for details of the GTAP model. 
Acknowledging the current states of both policy concerns in aid and trade and developments of tools to empirically analyze those economic impacts, this paper will discuss the impact of Japanese economic cooperation measures by means of CGE model simulations. The most recent Japanese policies in aid and trade are compared with an emphasis of relative efficiencies from the perspectives of economic welfare.

\section{2. GTAP Model}

A CGE model numerically simulates the general equilibrium structure of the economy. It is built on the Walrasian general equilibrium system, in which the central idea is that market demand equals supply for all commodities at a set of relative prices. Moreover, a CGE model has solid micro-foundations that are theoretically transparent. Functional forms are specified in an explicit manner, and interdependencies and feedback are incorporated. Therefore, the model provides a framework for assessing the effects of policy and structural changes on resource allocation by clarifying "who gains and who loses."

These characteristics differentiate it from the partial equilibrium model, which is not economy-wide, the macroeconomic model, which is not multi-sectoral, and the input-output model, in which agents do not respond to changes in prices. Moreover, the multi-country model is required to analyze international economic affairs such as trade and investment policies, which affect not just one but a number of economies.

The GTAP model is a standard CGE model, which depicts the behavior of households, governments, and global sectors across each economy in the world. It is composed of regional models, which are linked through international trade. Prices and quantities are simultaneously determined in factor markets and commodity markets by accounting relationships, by the equilibrium conditions specified by the behavior of economic agents, and by the structure of international trade. The model includes three main factors of production: labor, capital, and land. Labor and capital are used by all industries, but land is used only in agricultural sectors. Capital and intermediate inputs are traded, while labor and land are not traded between regions.

The standard version of the GTAP model includes several key assumptions. ${ }^{15}$ First, perfect competition, therefore constant return to scale, is assumed. Second, imperfect substitution in goods and services between the home economy and abroad and those among different origins of economies are assumed by Armington parameters. Third, the amount of total labor-one factor endowment-is fixed. This means that the model assumes full employment and no unemployment. The amount of total capital is also fixed in the standard GTAP model.

However, a standard version of the GTAP model can be modified that deal with capital formation. Important "dynamic" effects of capital accumulation are introduced ${ }^{16}$ into the standard static model. According to the growth theory, a medium-run growth or accumulation

15 It must be noted that the outcomes of model simulations may vary according to these macroeconomic assumptions and closures. These variations are suggested not just in terms of magnitude but also in direction. See, for example, Kawasaki (1999) for a diagnostic analysis of such model sensitivities in case of simulations on the impact of trade liberalization.

${ }^{16}$ See Francois, McDonald and Nordstrom (1996) for the methodology to implement this mechanism into the GTAP model. 
effect induces additional savings and investment. The induced savings ${ }^{17}$ and investment (larger capital stock) in turn links to the production capacities and causes a further increase in income. ${ }^{18}$

The GTAP database currently consists of 57 disaggregated sectors and 66 economies, ${ }^{19}$ which are aggregated to the appropriate version for simulations. In this study, economies are aggregated into 15 areas, and six areas are allocated to the larger six Asian recipient countries. Those are China, Indonesia, Malaysia, the Philippines, Thailand, and Vietnam, whose benefits from Japanese economic cooperation measures are analyzed in this paper. Industries/commodities are aggregated to eight, following a classification in the sectors of ODA loans.

\section{3. Assumptions}

In this paper, two model simulations are carried out. One is on the impact of Japan's ODA capital flows ${ }^{20}$ to the six Asian countries listed above. Another is that of unilateral trade liberalization of Japan for imports from those countries. The precise designs of these two experiments are discussed below.

\section{3. 1. ODA loans}

It is assumed that the entire amounts of Japan's ODA loans ${ }^{21}$ are spent for the construction of infrastructures in the recipient countries, ${ }^{22}$ which result in expansion of capital stocks. $^{23}$ On the other hand, it is assumed that capital formation is reduced in Japan by the corresponding amount of total flows of ODA loans to the six Asian countries compared with instances where this is not the case.

The annual size of such total amount of capital flows is calculated by a simple five- year average (1996 to 2000) of Japan's ODA loans to Asian countries in terms of gross-disbursement, ${ }^{24}$ as shown in Chart $4 .^{25}$ Sectoral disaggregation of these total ODA

${ }^{17}$ It is assumed that a fixed share of induced income is saved. The saving ratio is exogenous rather than endogenous in the current model.

${ }^{18}$ The trade, therefore, current balance is endogenous. However, rates of return on capital are not equalized across the regions through anticipated international capital flows. The model simulations show the outcomes of medium-term adjustments rather than theoretical long-term equilibrium.

${ }^{19}$ This is the version 5 database, which was released in summer 2002. Although, whose base year is 1997.

${ }^{20}$ The impact of other schemes of Japan's economic cooperation measures such that grand and technological cooperation is not analyzed in the model simulations.

${ }^{21}$ Those are total amounts for project loans. Those for commodity loans are not included.

${ }^{22}$ It is assumed that no part of Japan's ODA loans is tied to contract and procurement of Japanese goods and services. Transactions of goods and services among the regions are solved in the model without any constraints in this regard.

${ }^{23}$ There is no distinction in the model whether such capital inflows are private like FDI, or public like ODA loans. See Hermann (1996) for one methodology to evaluate FDI inflows in the GTAP model. The same methodology is employed in this paper to assess the impact of ODA capital inflows.

${ }^{24}$ This amount corresponds to actual progress in the progress of projects. The net amount of Japan's capital flows is shown in terms of net-disbursement. Moreover, from the viewpoint of measuring the size of expenditures for economic cooperation, it may be noted that 
loans ${ }^{26}$ is guided by the cumulated ODA loans by sector at the end of fiscal 2000. Exogenous shocks implemented in the model simulation are shown in Table $1 .^{27}$

[Table 1: ODA Capital Flows to Asian Countries]

\section{3. 2. Trade liberalization}

Instead of providing ODA loans, it is assumed that Japan will unilaterally eliminate protection on the import of goods from the six Asian countries. This means that Japanese import protection for the other economies remains unchanged. Moreover, import protection of the other countries, including the six Asian countries and not Japan, also remains unchanged. The magnitudes of such exogenous shocks on Japanese import prices are shown in Table 2, which are compared with the import protection in those six Asian countries that Japan faces.

[Table 2: Import Protection]

According to the protection data in the current GTAP database, ${ }^{28}$ it is shown that Japanese import protection is still significantly high in the primary sectors compared with that in the manufacturing sectors. Moreover, variation in the import protection among the countries within the same sectors is also suggested. ${ }^{29}$

\section{Simulation Results}

The main purpose of this paper is to compare the economic impacts of Japan's ODA loans to Asian countries with that of other Japanese external policy measures such as trade liberalization, while employing the same version of the economic model for simulation experiments. Before doing such comparison, however, the impacts of these two policy measures will be presented first.

It must be noted that the estimated economic impact by the CGE model is not a forecast. As described in Dee et al. (1996), economic policy measures will be implemented over time and adjustments to those changes may take time. During the course of such adjustments, other economic changes will also take place. However, those changes, including economic growth and structural changes in trade and industries, are not taken into account in the current analysis. The model simulation shows the differences at a certain point in time between when economic

concessionaity is not taken in account in either gross or net disbursement.

${ }^{25}$ The annual average total amount of Japan's ODA loans to the six Asian countries accounts for around 0.26 per cent of Japanese capital production.

${ }^{26}$ These figures are not published by the authorities.

${ }^{27}$ Therefore, these figures do not necessarily show the actual amount of Japan's ODA loans to the six Asian countries in 1996 to 2000 by sector. They are more likely the average of much longer trends from the beginning of Japan's ODA loans.

${ }^{28}$ The protection data in the GTAP database are expressed in the form of ad valorem equivalent, tariff, and non-tariff barriers. The best-quality data are those relating to tariffs. Non-tariff information is most complete in the cases of agriculture and textiles/apparel. Data for subsidies are also available distinguishing those for factor-based, intermediates, and ordinary output. However, the data are not comprehensive. Protection of the service sector is especially difficult to quantify and is mostly neglected in the current database.

${ }^{29}$ It may be noted that China's accession to WTO is not reflected in the current GTAP database. 
cooperation measures were implemented and when they were not.

\section{1. Impact of Individual Measures}

\section{1. 1. ODA loans}

The macroeconomic impact of capital formation in the six Asian countries by the inflows of Japan's ODA loans is summarized in Table 3. Investment and capital accumulation are key elements for economic growth. Capital inflows from abroad enable the recipient countries to invest more than domestic savings. Expansion of capital stock, and therefore production capacity, would raise the permanent level of real GDP compared instances in which this is not the case. This magnitude ranges from 0.1 per cent in China to 1.6 per cent in Vietnam in terms of the rate of change. It is a sizable impact, however, and it must be admitted that the relative contribution of ODA capital flows to economic growth may be limited in light of the recent rapid economic growth (from 5 per cent to 10 per cent) in these countries.

\section{[Table 3: Impact of Japan’s ODA Loans]}

Expansion of production capacity is expected to lower production prices. ${ }^{30}$ In fact, the current simulation suggests that the GDP price index would decline by 0.1 per cent to 0.7 per cent in the six Asian recipient countries. Lower production prices would enhance the competitiveness of those countries in the international market. Export volumes would increase due to these price effects. Moreover, import volumes would be stimulated by the income effects according to the expansion of the economy on the one hand, while those could be mitigated by the same price effects on the other hand. The current simulation shows that both export and import volumes would increase but those rates of changes in exports would tend to be larger than those in imports.

One concern in the analysis of the FDI behavior and developments is whether FDI and trade can be substitutes or complements. The theoretical literature indicates that these depend on the assumptions. In the empirical works, earlier general equilibrium modeling studies of $\mathrm{FDI}^{31}$ have generally concluded that FDI and trade are likely to be complements at the economy-wide level. The current simulation outcomes are in line with these studies that show capital inflows by means of the Japan's ODA loans in the Asian countries would create rather than destroy trade. However, the current framework of a CGE model does not explicitly incorporate the behavior of $\mathrm{FDI}^{32}$ and other capital movements. Therefore, the relationship between trade and investment is an issue to be further elaborated in the future.

As far as the efficiency of resource allocation is concerned, capital inflows raise the relative value of labor in the host countries, while a relative value of capital would decline. This would result in increases in wages and therefore a surplus in workers. On the other hand, if capital moves from capital-rich countries to capital-poor countries, the investor country gains a

${ }^{30}$ In general equilibrium model, only relative prices are important. The price of any factor endowments or goods in the model may be selected as a numéraire. All other prices are shown relative to the numéraire. In the current model simulations, a price index for the average price of capital goods supplied in each regions is chosen as a numéraire.

${ }^{31}$ See, for example, Petri (1997) and Dee and Hanslow (2000).

${ }^{32}$ See Hanslow et al. (2000) for the recent developments of a CGE model with FDI. 
larger return on the capital and enjoys surpluses. It is expected that international capital movements benefit both the investor and host countries by these efficiency effects.

The overall impact on economic welfare may also vary according to the terms of trade effect. The six Asian recipient countries would generally face deterioration of the terms of trade due to lower prices in the domestic market. In addition to the static impact of efficiency effects and terms of trade effects, the dynamic impact of capital formation may also be a concern. $^{33}$ In fact, welfare gains in the recipient countries are largely explained by capital formation rather than static efficiency and terms of trade effects. The rate of change in utility improvements ranges from 0.1 per cent to 1.0 per cent, which is relatively small compared with those changes in real GDP.

It is not surprising that those welfare gains may vary according to the sectors that ODA loans go into. Recipient countries tend to gain more from capital formation in the production and energy sectors. On the other hand, world-wide benefits are shown to be large in the case of capital formation in the manufacturing, trade and transportation sectors. Moreover, capital inflows to developing countries in an unspecified manner, rather than being limited those directions to a certain sector, would be much more beneficial.

The donor economy of Japan would lose rather than gain both in terms of real GDP and utility. This is primarily due to less capital formation according to the outflows of Japan's ODA capital. However, it must be noted that the income gains arising from investment abroad are not taken into account entirely in the current framework of model simulations. Including such income effects - which may not necessarily be large in the case of ODA loans compared with commercial loans - the negative impact on the Japanese economy could be limited to some extent.

\section{1. 2. Trade liberalization}

According to the conventional simulations by a CGE model of global trade, trade liberalization measures including tariff reductions would stimulate trade by lowering prices on tradable goods. This would result in increases in national output of exporting countries, while increasing access to the markets of trading partners. On the other hand, domestic production resources-land, capital, labor, and intermediate inputs - would be used more efficiently in importing countries in particular, when domestic distortions, including those due to trade barriers, are reduced. These combined effects-one from foreign markets and the other from the domestic market-are expected to result in the expansion of production and an increase in income and welfare.

The macroeconomic impact of import liberalization in Japan from the six Asian countries is summarized in Table 4. Although trade volumes for both exports and imports would generally be stimulated by a sizable amount, ${ }^{34}$ increases in real GDP could be relatively limited. This is not surprising because production in different sectors competes for a limited

${ }^{33}$ In the current framework model, one important dynamic effect of capital accumulation is already incorporated, as discussed above. However, other dynamic effects, such that through a rise in productivity by, among others, technology transfer, technology diffusion, and promotion of competition are not taken in account.

${ }^{34}$ Exports of the Philippines would exceptionally decrease. This is because of higher inflation mainly induced by significant expansion in Japanese demand for imports of agricultural products from the Philippines. 
supply of labor, capital, and land. An expansion of one sector would be accompanied by a contraction of another sector, except when the expansion is the result of significant resource accumulation or technological improvements. ${ }^{35}$

[Table 4: Impact of Japan's Import Liberalization]

In comparison with macroeconomic gains in real GDP, those gains measured in utility would be significantly larger in all six Asian countries. This is mainly due to terms of trade effects. Asian countries would gain larger benefits in terms of changes in Equivalent Variations, and therefore utilities, from unilateral import liberalization in Japan from those countries. It is indicated that terms of trade effects are much more significant compared with the efficiency effects of resource allocation discussed above.

One key issue in north-south trade has been these terms of trade effects on developing countries. There have been several interpretations and empirical studies concerning the reason why the persistent deterioration of terms of trade has been observed in the developing economies. One is to look at differences in the income elasticity of imports between north and south. ${ }^{36}$ Another is to attribute the higher growth in the south compared with the north. Moreover, trade policies of developed economies, which deteriorate the terms of trade in developing economies, have also been discussed on a number of occasions.

The current model simulations support that the trade protection in the developed countries such as Japan has been harmful for the economic welfare of developing countries such as neighboring Asian countries. From the perspective of development of Asian countries, it is also indicated that they could enjoy much more terms of trade gains from unilateral import liberalization in Japan without liberalizing their own markets, compared with those from reciprocal trade liberalization both in Japan and Asian countries. However, it must be noted that partial rather than broadly based trade liberalization may have the opposite effects generating significant economic losses. ${ }^{37}$

The impact of unilateral Japanese import liberalization on the Japanese economy is mixed. Japanese trade, including both imports and exports, would expand. Japanese prices would drop. These would result in increases in real GDP. These are entirely opposite outcomes compared with those according to Japan's ODA capital outflows. However, utility may still be lost because of terms of trade effects, which in turn significantly benefit Asian countries.

\section{2. Benefits and Costs of Aid and Trade}

Macroeconomic benefits of Japan’s ODA loans and Japanese import liberalization in the

${ }^{35}$ As it is noted in GATT (1994), a certain amount of increase in exports is not equivalent to the same amount of increase in production. To produce additional exports, resources that could otherwise have been used to produce goods and services for domestic residents must be used. The true net production gain is the difference between the increases in exports and the value of those "foregone" domestic goods and services.

${ }^{36}$ This is supported by the argument that export goods of the south are "necessities" whose income elasticity of imports in the north are low, while export goods of the north are "luxuries" whose income elasticity of imports in the south are high.

37 See Dee, Hardin and Schule (1998), who examined selected Early Voluntary Sectoral Liberalization (EVSL) by the APEC member economies. 
six Asian countries are compared in Chart 5. It may be argued that entire Japanese import liberalization takes place once and for all, while the disbursement of Japan's ODA loans continue over time. However, it may also be pointed out that both capital expenditures for ODA loans and tariff payment for trade protection are viewed as burdens by the Japanese taxpayers, ${ }^{38}$ at a macro level. The impact of annual expenditures for ODA loans is compared with that of tariff payment every year.

\section{[Chart 5: Comparison of Macroeconomic Gains]}

As far as ODA loans are used for capital formation, sizable impacts on economic growth are expected. Estimating the impact of the actual amount of ODA capital flows to Asian countries, those on real GDP are shown to be significantly larger compared with the potential impact of Japanese import liberalization from those countries.

In contrast, as far as improvements in economic welfare are concerned, trade liberalization is shown to be much more beneficial to most Asian countries. This is a reflection of composition of economic gains from two alternative economic cooperation measures. As discussed above, expansion in production capacities is a primary factor of the benefits from ODA loans. Moreover, terms of trade gains are a crucial source of economic benefits in unilateral—and therefore partial—-trade liberalization.

It may be pointed out that capital formation through ODA loans is effective for economic growth, while trade liberalization is efficient in welfare improvements. However, it does not necessarily mean that welfare improvements on average reduce poverty, as discussed above. In any event, two policy measures may more likely be complements rather than substitute for the development of developing countries.

In addition, it should be noted that reallocation of resources to more productive uses usually involves some adjustment costs. Implementation of certain policy measures in general would result in the displacing of employment across industries within the economies. Employment in obsolete industries declines, harming workers in those industries. In a rapidly changing economy, some of these workers may find themselves without the skills required for the new jobs being created.

It is shown from the estimated impacts on the structure of sectoral production that capital formation by Japan's ODA loans would result in increases in sectoral production without any exception in the six Asian countries. Furthermore, the relative magnitudes of increases in production by the sectors may largely be determined by the sectoral distribution of ODA loans.

In contrast, Japanese import liberalization may result in a realignment of regional production. In principle, it would be in accordance with comparative advantage of the regions. According to conventional simulations by a CGE model of global trade, developing and transition economies are expected to expand production and exports of labor-intensive manufactured products as a result of broadly based trade liberalization measures.

However, such an impact may more likely be determined by degree of import liberalization by the sectors in the case of partial trade liberalization. The current simulations

${ }^{38}$ As far as the fiscal balance of Japanese public sector is concerned, capital outflows are viewed as expenditures, while import protection, including custom tariffs, are viewed as revenue. They offset one another, when considering the impact on public balances. 
do not give such developments by the sufficiently disaggregated sectors. It is suggested that China and the Philippines would gain in primary sectors but lose in manufacturing sectors as a whole. On the other hand, contractions in several tertiary industries are suggested in some countries due to reallocation of production resources within the countries.

On the other hand, Japanese people may be concerned about the total amounts of ODA loans and trade protection in terms of the appropriate size of the government. In addition, sectoral variations in those payments and protections may be a much more serious concern from the viewpoint of distribution effects. ODA outflows are thought to be beneficial to certain exporting industries, while import protection could support non-tradable sheltered industries.

\section{Conclusions and Recommendations}

The main objective of this paper is to overview the developments of Japan's ODA and assess their economic impacts on Asian countries. It has attempted to provide quantitative evaluation of Japanese economic cooperation measures by means of economic model simulations. The benefits of two alternative measures-one from capital formation by Japan's ODA loans and the other from import liberalization in the Japanese market-are compared in view of the relative efficiencies of the economic policy measures. Key observations and findings are summarized as follows.

Allocation of Japan's ODA both by region and sector would be reviewed. The appropriate amount of ODA to each country may vary when seen in terms of total value or scaled by a certain macro indicator such as population. In addition, trends in Japan's ODA over time do not necessarily reflect the structural changes in Japanese trade and investment in Asian economies. In this regard, Japan's ODA to China is not necessarily huge, while that to Indonesia is still over-represented relative to the other countries.

As far as macroeconomic gains of Japanese economic cooperation measures in recipient countries are concerned, capital formation through ODA loans is effective for economic growth, while trade liberalization is efficient in welfare improvements. The two policy measures may more likely be complements rather than substitutes for the development of developing countries. Moreover, it must be noted that sectoral effects would be significantly different between the two policy measures of aid and trade both on the recipient and donor countries. A better policy mix may be sought in view of these distribution effects by sector, in addition to the appropriate size of policy measures in total.

Japan's ODA has been called a "tool” of diplomatic policy. However, the geographical and sectoral distribution of aid need to be reviewed, first, in views of the effectiveness and efficiency of aid and trade for economic development, and second, in light of economic trends such as trade and investment.

\section{References}

APEC (1995), 1995 Report on the APEC Regional Economy, Asia Pacific Economic Cooperation, Singapore

APEC (1997), The Impact of Trade Liberalization in APEC, Economic Committee, Asia Pacific Economic Cooperation, Singapore

Dee P., C. Geisler, G. Watts (1996), The Impact of APEC's Free Trade Commitment, Staff 
Information Paper, AGPS, Canberra

Dee, P. and K. Hanslow (2000), Multilateral Liberalization of Services Trade, Productivity Commission Staff Paper, AusInfo, Canberra

Dee, P., A. Hardin and M. Schule (1998), APEC Early Voluntary Sectoral Liberalization, Productivity Commission Staff Research Paper, AusInfo, Canberra

Francois, J. F., B. J. McDonals and H. Nordstrom (1996), "Liberalization and Capital Accumulation in the GTAP Model”, GTAP Technical Paper No. 7

GATT (1994), “The results of the Uruguay Round of Multilateral Trade Negotiations”, General Agreement on Tariffs and Trade

Hansen, H. and F. Tarp (2000), “Aid Effectiveness Disputed”, Journal of International Development, Vol. 12 N0. 3

Hanslow, K., T. Phamduc and G. Verikios (2000), The Structure of the FTAP Model, Research Memorandum MC-58, Productivity Commission, Canberra

Hermann, L. (1996), Foreign Direct Investment and Technology Transfer in Transition Economies: An Application of the GTAP Model”, HUMBOLDT-UNIVERSITAT ZU BERLIN Working Paper Nr. 28

Hertel, T. W. (1997), Global Trade Analysis: Modeling and Applications, Cambridge University Press, Cambridge

Herterl, T. W., P. V. Preckel, J. A. L. Cranfield and M. Ivanic (2002), "Poverty Impacts of Multilateral Trade Liberalization”, paper presented at the fifth Conference on Global Economic Analysis, Taipei

Kawasaki, K. (1999), Applications of the Computable General Equilibrium Model: Simulation Analysis on Trade Liberalization and Regulatory Reform, NIHONHYORONSYA, Tokyo (in Japanese)

MoFA (2003), Japan's Official Development Assistance 2002, Ministry of Foreign Affairs, Tokyo

Nishigaki, A. and Y. Shimomura (1999), The Economics of Development Assistance, LTCB International Library Selection No. 7, LTCB International Library Foundation, Tokyo

OECD (2002), 2001 DAC Chair's Report, Organization for Economic Cooperation and Development, Paris

Petri, P.A. (1997), "Foreign Direct Investment in a Computable General Equilibrium Framework," paper prepared for the conference, Making APEC Work: Economic Challenges and Policy Alternatives, 13-14 March, Keio University, Tokyo

Shimomura, Y., J. Nakagawa and J. Saito (1999), Political Economy of the ODA Charter, YUHIKAKU, Tokyo (in Japanese)

Shoven, J. B. and j. Whalley (1992), Applying General Equilibrium, Cambridge University Press, Cambridge

UNCTAD (2002), The World Investment Report 2002: TNCs and Export Competitiveness, United Nations, New York and Geneva

World Bank (1998), Assessing Aid: What Works, What Doesn't and Why, World Bank, Washington DC 


\section{Chart 1: Geographical Distribution of Japan's ODA (2001)}

(Billion US dollars)

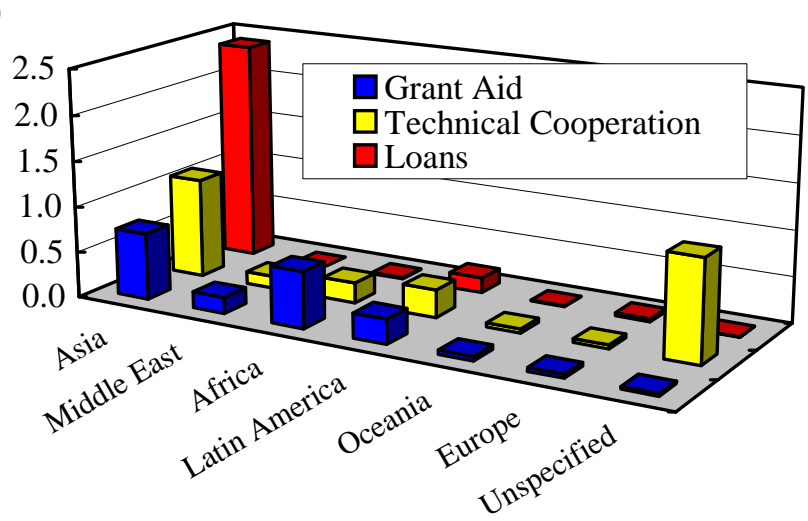

Source: Japan’s Official Development Assistance 2002 , Ministry of Foreign Affairs

\section{Chart 2: Relative Level of ODA}

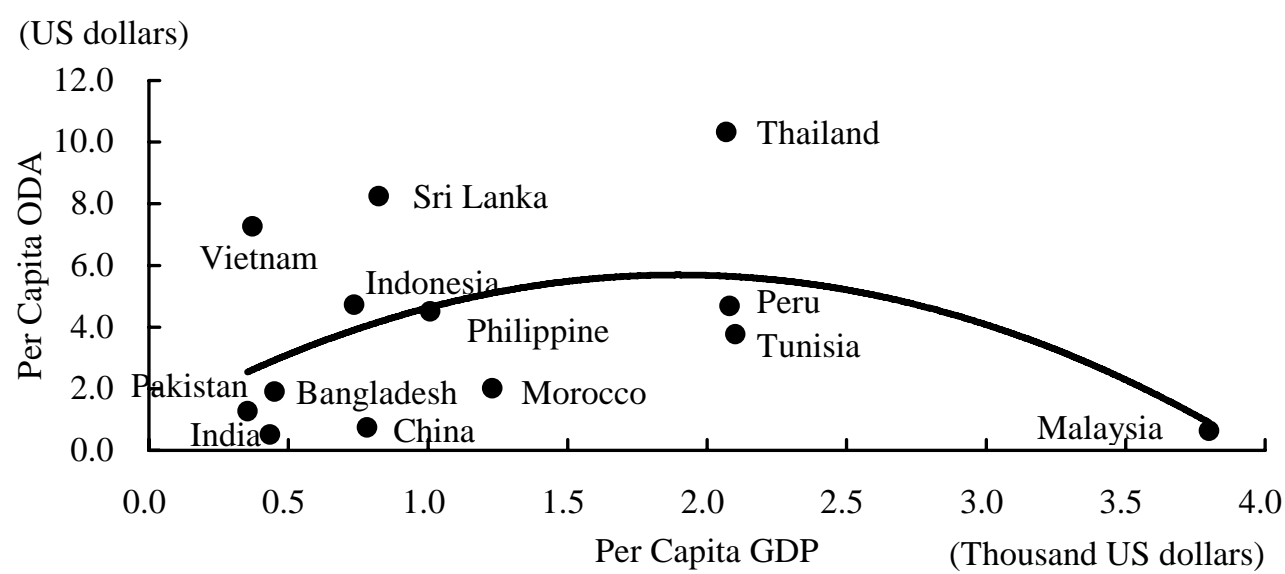

Source: Japan’s Official Development Assistance, Ministry of Foreign Affairs

\section{Chart 3: Sources of Japan's Imports}

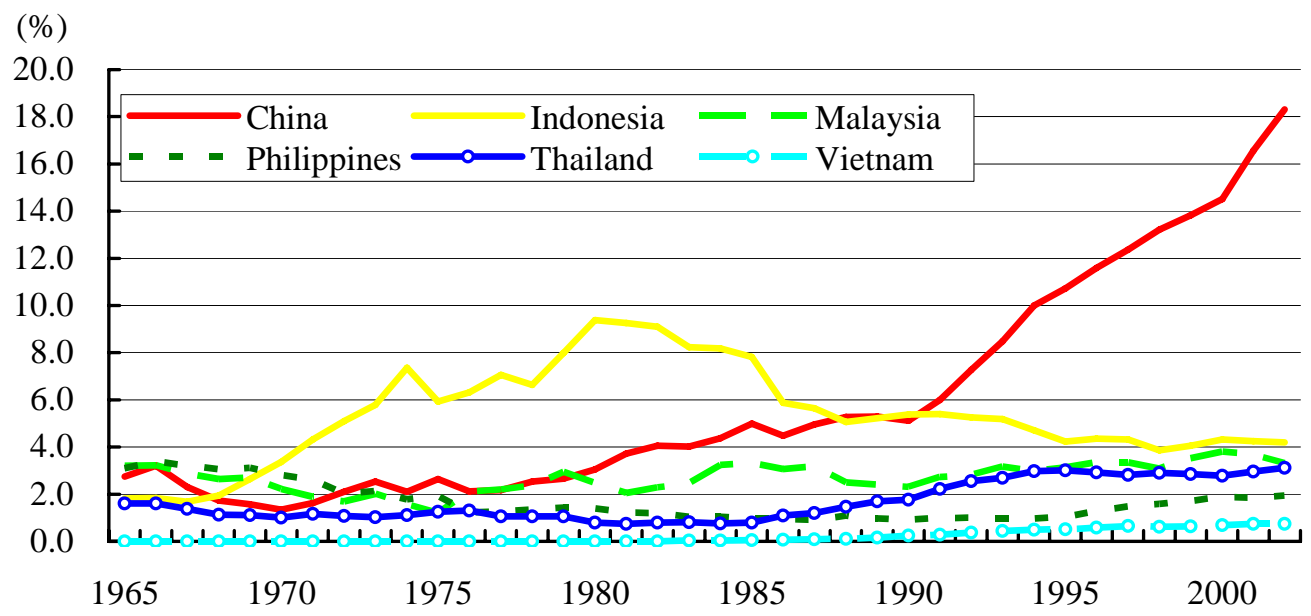

Source: Trade Statistics, Ministry of Finance 


\section{Chart 4: Trends in Flows of FDI and ODA Loans}
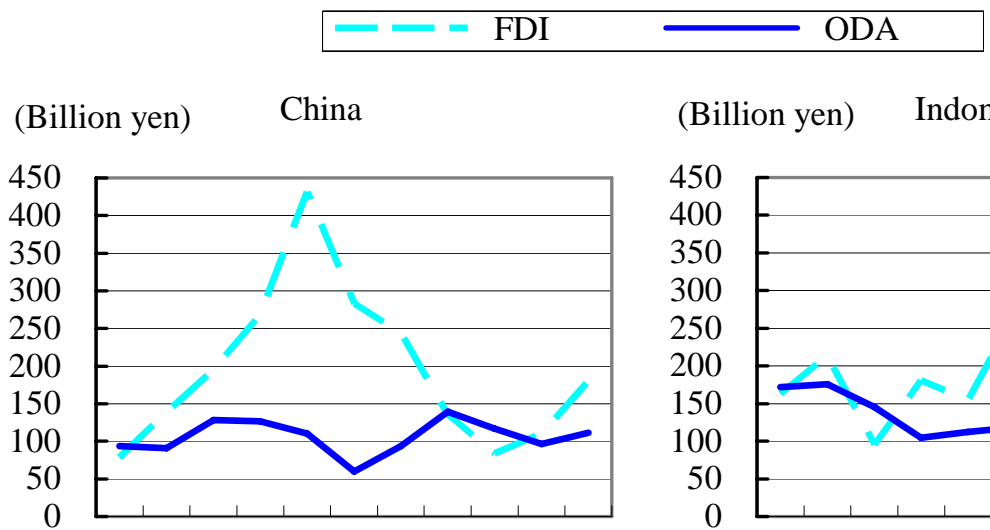

(Billion yen) Indonesia
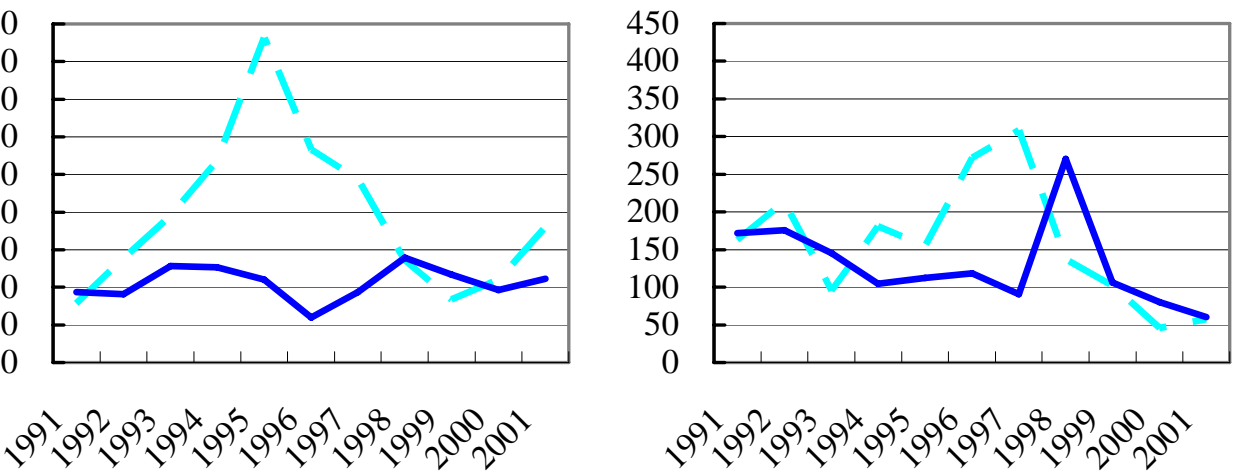

(Billion yen) Malaysia

(Billion yen) Phillipines
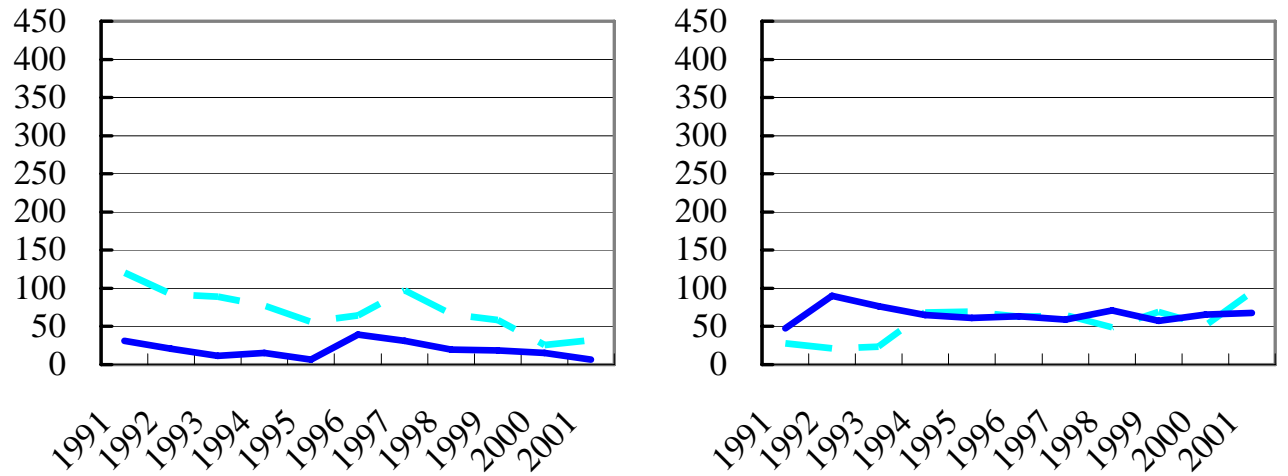

(Billion yen) Thailand

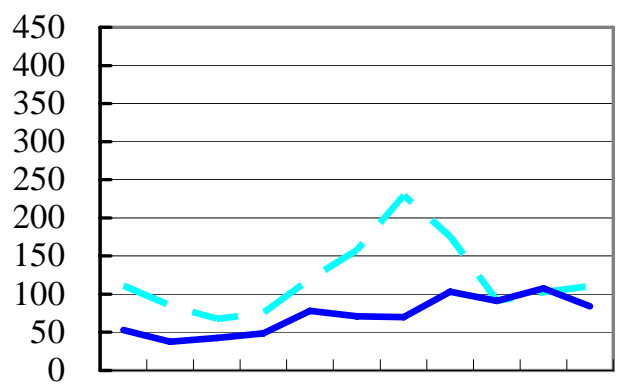

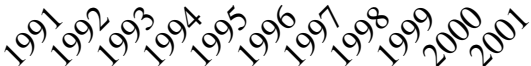

(Billion yen) Vietnam

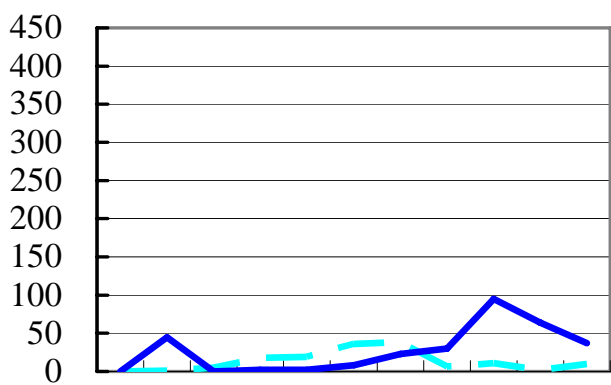

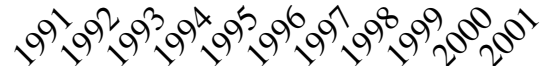

Source: Ministry of Finance Statistics Monthly, Ministry of Finance Annual Report of JBIC , Japan Bank for International Cooperation 
Table 1: ODA Capital Flows to Asian Countries

\begin{tabular}{lrrrrrrr} 
& & & \multicolumn{6}{c}{ (Average percentage of sectoral capitals in 1996 - 2000) } \\
& AGR & \multicolumn{1}{c}{ MFG } & \multicolumn{1}{c}{ EGW } & \multicolumn{1}{c}{ T_T } & CMN & PUB & \multicolumn{1}{c}{ Total } \\
\hline China & 0.27 & 0.02 & 3.26 & 1.03 & 0.43 & 1.11 & 0.31 \\
Indonesia & 0.39 & 0.29 & 28.85 & 1.46 & 3.64 & 1.58 & 1.11 \\
Malaysia & 0.07 & 0.11 & 10.11 & 0.23 & 0.32 & 3.22 & 0.38 \\
Philippines & 1.05 & 0.64 & 9.09 & 2.38 & 3.45 & 5.65 & 1.55 \\
Thailand & 1.12 & 0.09 & 3.99 & 1.45 & 4.02 & 3.51 & 0.65 \\
Vietnam & 0.00 & 0.19 & 137.78 & 22.61 & 68.29 & 29.14 & 4.05 \\
\hline
\end{tabular}

Note: Mnemonics stand for as follows:

AGR: Agriculture, Forestry and Fisherir

MFG: Mining and Manufacturing;

EGW: Electricity, Gas and Water;

CMN: Communication;

T_T: Trade and Transportation;

PUB: Public services.

Source: Author's calculations based on GTAP database Version 5 and

Annual Report of JBIC , Japan Bank for International Cooperation

Table 2: Import Protection

\begin{tabular}{lrrrrrr} 
& \multicolumn{3}{c}{ Japanese Import } & \multicolumn{3}{c}{ Japanese Export } \\
& Primary & \multicolumn{1}{c}{ Secodary } & \multicolumn{1}{c}{ Average } & Primary & Secodary & Average \\
\hline China & 33.2 & 8.0 & 8.6 & 11.3 & 15.6 & 15.2 \\
Indonesia & 14.2 & 5.6 & 5.5 & 11.1 & 9.9 & 9.6 \\
Malaysia & 2.7 & 2.0 & 1.9 & 40.0 & 8.5 & 8.4 \\
Philippines & 40.8 & 3.5 & 5.6 & 20.0 & 6.4 & 6.2 \\
Thailand & 22.8 & 14.9 & 13.4 & 33.3 & 17.3 & 16.8 \\
Vietnam & 19.7 & 12.0 & 11.5 & 0.0 & 19.0 & 17.5 \\
\hline World & 42.1 & 6.8 & 7.0 & 12.2 & 7.0 & 6.1 \\
\hline
\end{tabular}

Source: GTAP database Version 5

Table 3: Impact of Jpan's ODA Loans

\begin{tabular}{lrrrrrr} 
& Real GDP & $\begin{array}{c}\text { Export } \\
\text { Volume }\end{array}$ & $\begin{array}{c}\text { Import } \\
\text { Volume }\end{array}$ & $\begin{array}{c}\text { GDP } \\
\text { Deflator }\end{array}$ & $\begin{array}{c}\text { Trade } \\
\text { Balance* }\end{array}$ & Utility \\
\hline Japan & -0.10 & -0.12 & -0.01 & 0.03 & -387 & -0.07 \\
\hline China & 0.12 & 0.14 & 0.05 & -0.06 & 139 & 0.08 \\
Indonesia & 0.50 & 0.59 & 0.35 & -0.22 & 67 & 0.41 \\
Malaysia & 0.20 & 0.19 & 0.16 & -0.13 & 13 & 0.14 \\
Philippines & 0.71 & 0.90 & 0.54 & -0.60 & 6 & 0.49 \\
Thailand & 0.49 & 0.34 & 0.20 & -0.29 & 29 & 0.42 \\
Vietnam & 1.65 & 2.53 & 1.24 & -0.69 & 28 & 0.99 \\
\hline World & 0.00 & 0.02 & 0.02 & -0.01 & 0 & 0.00 \\
\hline
\end{tabular}

Note: Deviations in million US dollars 
Table 4: Impact of Jpan's Import Liberalization

(\%)

\begin{tabular}{lrrrrrr} 
& Real GDP & $\begin{array}{c}\text { Export } \\
\text { Volume }\end{array}$ & $\begin{array}{c}\text { Import } \\
\text { Volume }\end{array}$ & $\begin{array}{c}\text { GDP } \\
\text { Deflator }\end{array}$ & $\begin{array}{c}\text { Trade } \\
\text { Balance* }\end{array}$ & \begin{tabular}{c} 
Utility \\
\hline Japan
\end{tabular} \\
\hline China & 0.06 & 2.85 & 2.87 & -0.45 & -790 & -0.11 \\
Indonesia & 0.08 & 1.82 & 2.73 & 1.51 & 1,514 & 0.78 \\
Malaysia & 0.06 & 0.87 & 1.51 & 1.10 & 168 & 0.49 \\
Philippines & 0.05 & 0.10 & 0.16 & 0.16 & 33 & 0.16 \\
Thailand & 0.00 & -0.36 & 0.34 & 1.10 & -72 & 0.43 \\
Vietnam & 0.22 & 2.21 & 3.52 & 2.29 & 617 & 1.56 \\
World & 0.21 & 1.80 & 3.32 & 4.23 & -20 & 1.86 \\
\hline
\end{tabular}

Note: Deviations in million US dollars

Chart 5: Comparison of Macroeconomic Gains

: ODA Loans

Real GDP

2.5

2.0

1.5

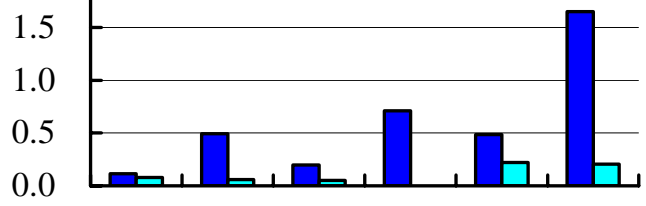

0.0

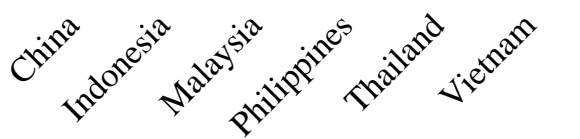

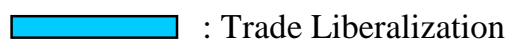

(\%) Utility

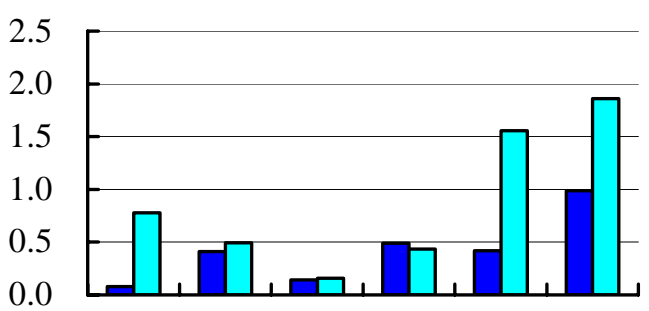

